\title{
A Caddo Ceramic Vessel from the Atkinson Farm Site (41RR1), Red River County, Texas
}

Timothy K. Perttula

Heritage Research Center, Stephen F. Austin State University

Follow this and additional works at: https://scholarworks.sfasu.edu/ita

Part of the American Material Culture Commons, Archaeological Anthropology Commons, Environmental Studies Commons, Other American Studies Commons, Other Arts and Humanities Commons, Other History of Art, Architecture, and Archaeology Commons, and the United States History Commons

Tell us how this article helped you.

This Article is brought to you for free and open access by the Center for Regional Heritage Research at SFA ScholarWorks. It has been accepted for inclusion in Index of Texas Archaeology: Open Access Gray Literature from the Lone Star State by an authorized editor of SFA ScholarWorks. For more information, please contact cdsscholarworks@sfasu.edu. 


\section{A Caddo Ceramic Vessel from the Atkinson Farm Site (41RR1), Red River County,}

Texas

\section{Creative Commons License}

\section{(c) (1) (8)}

This work is licensed under a Creative Commons Attribution-NonCommercial 4.0 International License 


\title{
A Caddo Ceramic Vessel from the Atkinson Farm Site (41RR1), Red River County, Texas
}

\author{
Timothy K. Perttula
}

The Atkinson Farm site (41RR1) is an ancestral Caddo settlement on the Mound Prairie area of the Red River alluvial valley, about midway between the Wright Plantation site (41RR7) to the west and the Sam Kaufman site (41RR16) to the east. The site was investigated by B. B. Gardner of The University of Texas in 1930. At that time, he exposed and investigated the remains of three burials, one of which had five ceramic vessels placed with it as funerary offerings; the vessels had been damaged and broken by previous plowing. One of the vessels from this burial remains in the collections at the Texas Archeological Research Laboratory at The University of Texas.

SITE NAME OR SITE NUMBER: Atkinson Farm (41RR1)

VESSEL NO.: 1

VESSEL FORM: Jar

NON-PLASTICS AND PASTE: shell

RIM AND LIP FORM: N/A

CORE COLOR: F (fired in a reducing environment and cooled in the open air)

INTERIOR SURFACE COLOR: reddish-brown

EXTERIOR SURFACE COLOR: reddish-brown; fire clouds on the body

WALL THICKNESS (IN MM): body, $5.3 \mathrm{~mm}$

INTERIOR SURFACE TREATMENT: smoothed

EXTERIOR SURFACE TREATMENT: smoothed between appliqued fillets

HEIGHT (IN CM): N/A

ORIFICE DIAMETER (IN CM): 12.7 [as measured on the body]

DIAMETER AT BOTTOM OF RIM OR NECK (IN CM): N/A

BASE DIAMETER (IN CM) AND SHAPE OF BASE: $5.7 \mathrm{~cm}$, circular and flat

ESTIMATED VOLUME (IN LITERS): N/A 
DECORATION (INCLUDING MOTIF AND ELEMENTS WHEN APPARENT): The rim is missing, but the vessel body has four sets of two closely-spaced vertical appliqued fillets (with a total width of 10.3 $\mathrm{mm})$. The fillets extend to within $2 \mathrm{~cm}$ of the vessel base

\section{PIGMENT USE AND LOCATION ON VESSEL: none}

TYPE AND VARIETY (IF KNOWN): cf. McKinney Plain (Suhm and Jelks 1962:Plate 49a, h) or Nash Neck Banded (Suhm and Jelks 1962:Plate 56d, f, j)

Gardner also recovered over 100 ceramic sherds and one elbow pipe fragment in the excavations at the Atkinson Farm site. About 30 of the sherds are from three separate vessel sections, and include a Nash Neck Banded jar, a red-slipped engraved vessel (probably Avery Engraved, given the common use of a red slip to cover interior and exterior surfaces of many vessels, see Suhm and Jelks 1962:1), and a Hudson Engraved vessel. One rim sherd has an appliqued decoration, and two others have either punctated or punctated-appliqued decorative elements (probably from an Emory Punctated-Incised jar). Also in the collection were one plain rim sherd and 52 plain body sherds.

This shell-tempered vessel at the Atkinson Farm site is from a Late Caddo period McCurtain phase burial feature (ca. A.D. 1400-1680), and the sherds recovered by Gardner are from a contemporaneous habitation area. It is likely part of a settlement or farmstead compound associated with the extensive settlement of this part of the Red River valley by Caddo peoples, best exemplified by the settlements and cemeteries at the nearby Sam Kaufman site (Skinner et al. 1969; Perttula 2008).

\section{References Cited}

Perttula, T. K.

2008 The Archeology of the Roitsch Site (41RR16), an Early to Historic Caddo Period Village on the Red River in Northeast Texas. In Collected Papers from Past East Texas Archeological Society Summer Field Schools, edited by T. K. Perttula, pp. 313-628. Special Publication No. 5. Texas Archeological Society, San Antonio.

Skinner, S. A., R. K. Harris, and K. M. Anderson (editors)

1969 Archaeological Investigations at the Sam Kaufman Site, Red River County, Texas. Contributions in Anthropology No. 5. Department of Anthropology, Southern Methodist University, Dallas.

Suhm, D. A. and E. B. Jelks (editors)

1962 Handbook of Texas Archeology: Type Descriptions. Special Publication No. 1, Texas Archeological Society and Bulletin No. 4, Texas Memorial Museum, Austin. 